\title{
LARYNGOSCOPES, LIDOCAINE, AND LIABILITY: THE Absence of ImMUnity Protection for Prehospital PROVIDERS IN INDIANA
}

\author{
Meghan A. Cox
}

TABLE OF CONTENTS

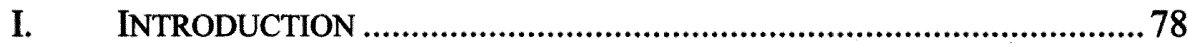

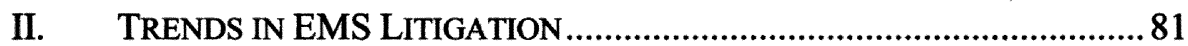

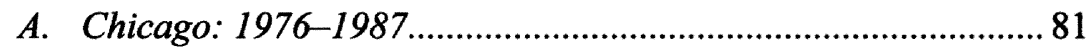

B. Miami-Dade County: 1972-1982 ………………….............. 81

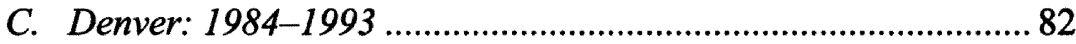

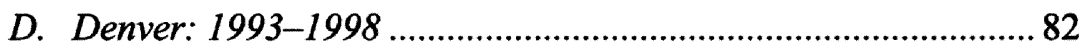

III. CONSTITUTIONAL CLAIMS INVOKING 42 U.S.C. § 1983 (“§1983”) .......83

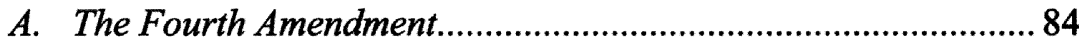

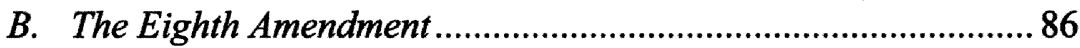

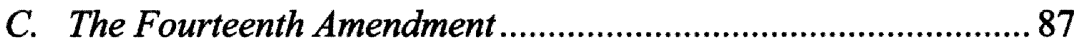

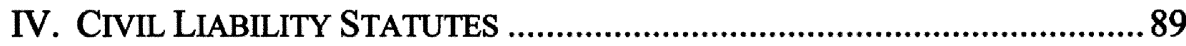

A. Statutory Provisions for Civil Liability in Indiana and

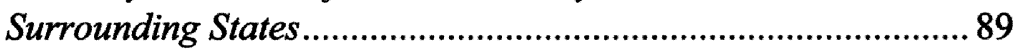

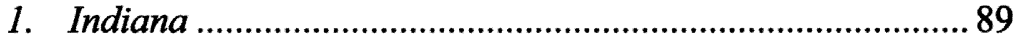

2. Michigan ......................................................................... 91

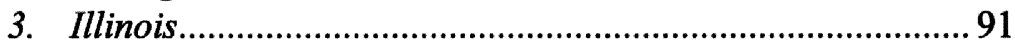

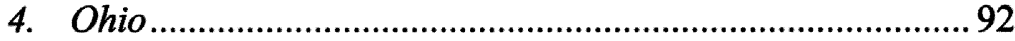

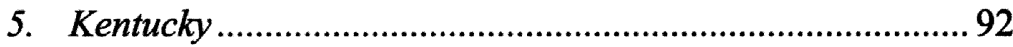

B. States Providing for Liability for Ordinary Negligence .............. 92

C. Application of Ordinary Negligence Standard to EMTs ............ 93

V. THE INDIANA MEDICAL MALPRACTICE ACT .....................................94

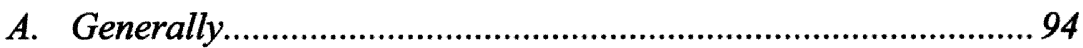

B. The Patient's Compensation Fund.............................................96

VI. THE POLICY CONSIDERATIONS DRIVING IMMUNITY..........................97

A. The State of EMS in Indiana ....................................................97

B. Other Statutory Grants of Immunity.......................................... 98

1. Indiana Code Section 16-31-6-4: Immunity in Disaster Emergency ....................................................................... 98

2. Indiana Code Section 34-30-12-1(b): Good Samaritan

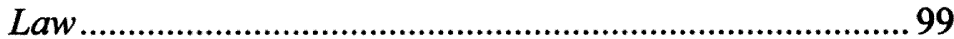

C. The Role of Firefighter/EMTs ................................................... 101

D. The Prevalence of Shiftwork .................................................... 102

* J.D. Candidate, 2009, Indiana University School of Law - Indianapolis; B.A., 2006, The College of William and Mary; Indiana Emergency Medical Technician - Basic. 


\section{INTRODUCTION}

On February 16, 1968, then-Alabama Speaker of the House, Rankin Fite, placed the first-ever 911 call from City Hall to the police station in Haleyville, Alabama. ${ }^{1}$ Thirty years later, President Clinton signed the Wireless Communications and Public Safety Act of 1999, which designated "911" as the nationwide emergency number. ${ }^{2}$ Since that first 911 call forty years ago, dramatic changes have occurred in the response provided to an emergency call, especially with regard to the provision of Emergency Medical Services ("EMS"). The public's expectations of emergency response have changed as well, but these changes may not necessarily reflect the reality of EMS.

Public expectations have been shaped largely by media portrayals of EMS response. ${ }^{3}$ Recent generations have been exposed to television shows devoted to the dramatization of emergency response. From 1972 to 1979 , for example, Emergency! aired on NBC and portrayed a fictional crew of Los Angeles County Fire Department paramedics responding to emergencies. ${ }^{4}$ From 1989 to 1996, Rescue 911 aired on CBS and featured dramatic reenactments of situations leading up to and following 911 calls. ${ }^{5}$ The show was devoted almost entirely to successful rescues. ${ }^{6}$ Other, more recent shows, such as E.R. and Chicago Hope, have continued to provide a glimpse into emergency medical care. The dramatic and selective nature of these shows has generated the perception that virtually all prehospital interventions are successful. ${ }^{7}$

Of emergencies portrayed on television, the resuscitation of cardiac arrest patients exhibits the greatest discrepancy between how it is portrayed on television and actual statistics. ${ }^{8}$ A 1996 study of the television programs Chicago Hope, ER, and Rescue 911 found that the programs gave misleading portrayals

1. See The History of 911 , Dispatch MONTHLY MAgAZINE, available at http://www.911dispatch.com/ 911/history (last visited Jan. 9, 2008).

2. 47 U.S.C.A. § 615 (West 1999).

3. Bryan Bledsoe, Have We Set the Bar Too High?, 32 J. EMERGENCY MED. SERvs. (March 2007), available at $\mathrm{http} / / / \mathrm{www} . j \mathrm{jems.com} / \mathrm{news}$ and_articles/articles/jems/3203/have _we_set_the_bar_too_high.html.

4. See Emergency! (1972), Internet Movie Database, Inc., http://imdb.com/title/ tt0068067 (last visited Feb. 6, 2009).

5. See Rescue 911 (1989), Internet Movie Database, Inc., http://imdb.com/title/ tt0096688/ (last visited Feb. 6, 2009).

6. Susan J. Diem, et al., Cardiopulmonary Resuscitation on Television, 334 NEw ENG. J. MED. 1578, 1581 (1996).

7. Bledsoe, supra note 3.

8. Id. 
of cardiopulmonary resuscitation ("CPR") ${ }^{9}$ and death in three ways. ${ }^{10}$ First, the study found that the shows inaccurately represented the types of people most commonly given CPR: on television, sixty-five percent of those given CPR were children, teenagers, or young adults; in reality, cardiac arrest is much more common in the elderly. ${ }^{11}$ Second, the study found that the shows inaccurately reflected the causes of cardiac arrest: only twenty-eight percent of those on television had a cardiac arrest attributable to underlying cardiac disease, as opposed to acute injury, such as gunshot wounds or motor vehicle collisions; in real life, underlying cardiac disease accounts for seventy-five to ninety-five percent of all cardiac arrests. ${ }^{12}$ Finally, the study found that CPR performed on the shows succeeded far more frequently than in real life: the three shows combined showed a seventy-five percent survival rate immediately after cardiac arrest; ${ }^{13}$ Rescue 911 , which admittedly focuses on the successes of emergency services, had a $100 \%$ post-CPR survival rate. ${ }^{14}$ These shows, and others like them, instill in the public an unrealistic impression of resuscitation efforts and their chances for success, showing overall survival rates significantly higher than the most optimistic statistics provided in medical literature. ${ }^{15}$

Public expectations have also been shaped by education campaigns designed to promote the use of 911 in emergencies. These public education programs have largely emphasized the importance of speed in obtaining an emergency response. ${ }^{16}$ Although response times less than four minutes from the time of patient collapse are highly correlated with improved resuscitation rates, ${ }^{17}$ it would be prohibitively expensive for most EMS agencies to consistently provide response times under four minutes. ${ }^{18}$ Many EMS systems have

9. American Heart Association, "Cardiopulmonary Resuscitation (CPR)," available at http://www.americanheart.org/presenter.jhtml?identifier=4479 ("CPR is a combination of rescue breathing and chest compressions delivered to victims thought to be in cardiac arrest. When cardiac arrest occurs, the heart stops pumping blood. CPR can support a small amount of blood flow to the heart and brain to 'buy time' until normal heart function is restored.").

10. Diem, et al., supra note 6, at 1580-81.

11. Id. at 1581 .

12. Id.

13. Id.

14. Id.

15. Jaqueline Brooks, Real CPR Isn't Everything It Seems to Be, WebMD, May 14, 2001, available at http://www.webmd.com/news/20010514/real-cpr-isnt-everything-seems-to-be ("[O]nly between 5\%-10\% of people who undergo CPR will survive."). See generally Diem, et al., supra note 6 , at 1578 .

16. Bledsoe, supra note 3.

17. Id.; see also Peter T. Pons \& Vincent J. Markovchick, Eight Minutes or Less: Does the Ambulance Response Time Guideline Impact Trauma Patient Outcome?, 23 J. EMERGENCY MED. 43, 45-46 (2002).

18. Pons \& Markovchick, supra note 17, at 47 ("It is not realistic to expect ever-shorter [. . .] ambulance response times to be the answer to meet all out-of-hospital medical needs and expectations. ... [T] here is a significant financial cost associated with lowering ambulance response times. To do so means the addition of ambulance vehicles and paramedic staff at an approximate annual cost of $\$ 400,000$ to $\$ 500,000$ per $24 \mathrm{~h} /$ day staffed ambulance."). 
an eight-minute target response time; ${ }^{19}$ however, a 2002 study found that "there is little evidence [. . .] to suggest that changing [. . . ] response time specifications to times less than current, but greater than 5 minutes, would have any beneficial effect on survival."20 EMS personnel are already "particularly vulnerable to malpractice allegations since they routinely treat patients in less than optimal locations with minimal if any history, no advance notice and with limited resources." 21 The added distortion of the importance of response times and the inflated survival rates portrayed to the public ${ }^{22}$ has primed the prehospital patient care relationship for litigation.

The purpose of this Note is to map out the scheme of civil liability for EMS providers in Indiana and call into question the absence of minimal immunity protections for them. ${ }^{23}$ Part II of this Note explores the increasing trends in litigation against EMS providers, as found in several studies conducted between 1972 and 1998. Part III explores the constitutional arguments that plaintiffs have made in attempting to hold EMTs liable for claimed deficiencies in the provision of emergency medical services. Part IV of this Note introduces the civil liability provisions in the Indiana Code applicable to EMTs and the standard of care that those provisions impose. It considers these statutory provisions, as compared to those of neighboring states. Part V considers the potential impact of the Indiana Medical Malpractice Act (the "Act") on EMS providers. Part VI considers the policy imperatives driving a grant of immunity for EMS providers. This Note concludes with the recommendation that, as a public policy matter, the Indiana General Assembly should provide immunity to EMTs for acts of ordinary negligence.

19. Bledsoe, supra note 3.

20. Thomas H. Blackwell \& Jay S. Kaufman, Response Time Effectiveness: Comparison of Response Time and Survival in an Urban Emergency Medical Services System, 9 ACAD. EMERGENCY MED. 288, 288 (2002).

21. Bruce M. Cohn \& Alan J. AZzara, Legal Aspects of Emergency Med. Serv. 8 (W.B. Saunders Company 1998).

22. See discussion of distorted portrayals of resuscitation on television, supra pages 2-3.

23. The state of Indiana, through the Indiana Department of Homeland Security, offers three main levels of EMS certification: Emergency Medical Technician ("EMT")- Basic, EMTIntermediate, and EMT-Paramedic. See IDHS: Emergency Medical Services Training Program, Indiana Dept. of Homeland Sec., available at $\mathrm{http}: / / \mathrm{www} . \mathrm{in} . \mathrm{gov} / \mathrm{dhs} / 2476 \mathrm{htm}$. (The state offers a fourth certification, EMT- Basic Advanced, which provides an Advanced Life Support ("ALS") supplement to the EMT- Basic training, and thus will be grouped with EMT- Basic in this Note). EMT- Basic is a Basic Life Support ("BLS") certification; EMT-Intermediate and EMT- Paramedic are ALS certifications. See 836 IND. ADMIN. CoDE 1-1-1(2) (2004). These certification levels correspond to the medical skills that a provider is trained and permitted to perform. Generally speaking, ALS providers can perform skills including endotracheal intubation, initiating intravenous ("IV") lines, drug administration, electrocardiogram interpretation, and operation of a manual defibrillator. See id. Indiana's EMS training standards are "established by the Indiana Emergency Medical Services Commission and either meet or exceed the standards set by the National Highway Traffic Safety Administration (NHTSA) for EMS programs." IDHS: Emergency Medical Services Training Program, Indiana Dept. of Homeland Sec., available at $\mathrm{http}: / / \mathrm{www}$.in.gov/dhs $/ 2476 . \mathrm{htm}$. For purposes of this Note, "EMT" will refer to all levels of certification, and "paramedic" will refer specifically to ALS personnel. 


\section{TRENDS IN EMS LITIGATION}

The focus of this Note is on liability for medical treatment rendered in the prehospital setting; therefore, the reader will note that it gives only limited consideration to other possible sources of litigation against EMS providers, such as problems with dispatch or motor vehicle accidents involving responding vehicles. Even though the studies examining litigation against EMS providers are generally not limited to claims for medical care, they are still illustrative of the general trends in this sort of litigation - trends which may influence, or be influenced by, the scheme of civil liability for EMS personnel in a given jurisdiction.

\section{A. Chicago: $1976-1987$}

One study reviewed all claims brought against the Chicago municipal ambulance service system from 1976 to $1987 .{ }^{24}$ Lawsuits alleging "improper medical treatment" accounted for seventy-seven percent of the claims. ${ }^{25}$ Overall, there was one lawsuit per 27,371 responses, and one lawsuit per 17,995 patient transports. ${ }^{26}$ Almost one-third of the lawsuits involved patients who suffered cardiac arrest. ${ }^{27}$ Patient death, regardless of cause, increased the likelihood of a lawsuit. $^{28}$ Noting that the most common cause of litigation involved acts of omission, the authors recommended that "prehospital providers should be encouraged to provide aggressive management when any doubt exists." 29 The study indicated an increasing number of claims filed against prehospital care providers over time ${ }^{30}$ trumpeting the importance of reconsidering the applicable schemes of civil liability.

\section{B. Miami-Dade County: 1972-1982}

Another study conducted during the formative stages of EMS found similar results - that is, a low risk of litigation during the period of the study with an increasing instance of complaints over time. ${ }^{31}$ This study looked at the claims filed against Dade County Fire Rescue in Miami-Dade County, Florida between 1972 and 1982, and found an incidence of one claim per 24,906

24. Richard J. Goldberg, et al, A Review of Prehospital Care Litigation in a Large Metropolitan EMS System, 19 ANNALS EMERGENCY MED. 557, 557 (1990).

25. Id.

26. Id. at 559 .

27. Id.

28. Id.

29. Goldberg, supra note 24, at 561 .

30. Id. at 557.

31. Joseph M. Soler et al, The Ten-Year Malpractice Experience of a Large Urban EMS System, 14 ANNALS EMERGENCY MED. 982, 982 (1985). 
runs. ${ }^{32}$ More than half of the claims filed during the ten-year study period were filed in the last three years of the study. ${ }^{33}$ The authors of the study offer some potential causes for this trend toward litigiousness, including "the belief that in the public's eye the 'new glow' of EMS has worn off; that yesterday's miracles are today's routine occurrences; that trauma system development points out the weaknesses and strengths of prehospital care $[\ldots]$ and that the public's sentiment is that all misfortunes are compensable events." ${ }^{34}$ This same theme is reiterated elsewhere: "[o]ne of the most common fallacies among lay persons is the belief that malpractice is always responsible if medical treatment yields a bad, unsatisfactory or unexpected result. ${ }^{, 35}$

\section{Denver: $1984-1993$}

Another study undertook a retrospective review of all claims made against the Denver Health Paramedic Division from 1984 to $1993{ }^{36}$ The study found an average of one claim per 5,084 runs. ${ }^{37}$ Motor vehicle accidents involving ambulances accounted for seventy-two percent of the claims, while claims specifically alleging medical negligence represented less than four percent of the claims. ${ }^{38}$ Notable, however, is that the medical negligence claims, while representing less than four percent of the claims, accounted for thirty-five percent of the monetary losses paid out in legal claims. ${ }^{39}$

\section{Denver: $1993-1998$}

A more recent study picked up where the previous research left off, looking at all complaints in Denver from 1993 to 1998, this time against the Denver Paramedic Division. ${ }^{40}$ The study, which was not limited to complaints brought for medical treatment, found a complaint rate of one per 1,075 ambulance responses, ${ }^{41}$ a complaint rate substantially higher than that of the Chicago and Miami-Dade County studies. Of these, complaints alleging improper medical treatment represented twenty percent of the complaints, ${ }^{42}$ but the number may be higher-- according to the authors of the study, some medical treatment issues also may have been categorized as "rude behavior," a category which

32. Id. at 983 .

33. $I d$. at 984 .

34. Id. at 985 .

35. COHN \& AZZARA, supra note 21 , at 8.

36. Christopher B. Colwell, et al, Claims Against a Paramedic Ambulance Service: A

Ten-Year Experience, 17 J. EMERGENCY MED. 999, 999 (1999).

37. Id. at 1000.

38. Id.

39. Id. at 999.

40. Christopher B. Colwell, et al, Complaints Against an EMS System, 25 J. EMERGENCY MED. 403, 404 (2003).

41. Id.

42. Id. at 406. 
represented another twenty-three percent of the claims. ${ }^{43}$ The authors of the study concluded that " $[\mathrm{t}]$ he identification of areas of high dissatisfaction will hopefully lead to targeting of quality and performance improvement programs directed at customer service and risk management. ${ }^{, 44}$ Conspicuously absent from this recommendation are programs addressing the technical proficiency of prehospital providers, which may simply be an acknowledgement that the conditions of prehospital emergency response are, by definition, less-than-ideal, and that it is inevitable that the conditions encountered in emergency response may sometimes surmount the resources available to prehospital providers in their efforts to provide medical care.

It would be a mistake to derive any specific conclusions from this or the other studies as none of them were conducted in Indiana, and are thus susceptible to the statutory provisions of their respective jurisdictions. It is, however, possible to discern a general trend toward increasing litigation involving EMS agencies and providers. This trend warrants a reexamination of the provisions governing potential liability for prehospital providers in Indiana.

\section{CONSTITUTIONAL ClAIMS INVOKING 42 U.S.C. § 1983 (“\$1983”)}

Plaintiffs often attempt to bypass potential state immunity for governmentemployed EMTs by filing claims alleging the deprivation of a federal constitutional right. ${ }^{45}$ These claims are brought under the authority of the Civil Rights Act of 1871, which declares that

[e]very person who, under color of any statute, ordinance, regulation, custom, or usage, of any State or Territory or the District of Columbia, subjects, or causes to be subjected, any citizen of the United States or other person within the jurisdiction thereof to the deprivation of any rights, privileges, or immunities secured by the Constitution and laws, shall be liable to the party injured in an action at law, suit in equity, or other proper proceeding for redress. ${ }^{46}$

The Seventh Circuit Court of Appeals once described $\$ 1983$ as "the ubiquitous tort remedy for deprivations of rights secured by federal law (primarily the Fourteenth Amendment) by persons acting under color of state law." ${ }^{, 47}$ Without alleging more than inept medical care, plaintiffs have generally failed to state

43. Id.

44. Id. at 408.

45. Philip Stittleburg, Force in Solicited Aid Not Always a Violation, FIRE CHIEF, Oct. 2007 , at 16 .

46. 42 U.S.C.A. § 1983 (West 1996).

47. Jackson v. City of Joliet, 715 F.2d 1200, 1201 (7th Cir. 1983). 
viable constitutional claims because "even if the complaints state good claims under general tort principles, it does not follow that they state good claims under $[\S] 1983$ just because the defendants are public officers. ${ }^{, 48}$ The decisions rejecting alleged constitutional violations for negligent emergency medical care are numerous and worth considering, especially in light of their policy implications.

\section{A. The Fourth Amendment}

The Fourth Amendment provides, in relevant part, that " $[\mathrm{t}] \mathrm{he}$ right of the people to be secure in their persons, houses, papers, and effects, against unreasonable searches and seizures, shall not be violated."49 Generally, moving a patient into an ambulance is not considered "custody" for purposes of the Fourth Amendment. ${ }^{50}$ Something more closely resembling a Fourth Amendment violation may arise when EMTs must restrain a patient in order to effectively administer medical aid, potentially running afoul of the prohibition on "unreasonable searches and seizures." 51

In Peete v. Nashville ${ }^{52}$ for example, EMTs restrained a man having an epileptic seizure, who then died shortly after being restrained. ${ }^{53}$ The court grappled with what is considered a "seizure" for purposes of the Fourth Amendment, distilling from precedent that it is "an intentional interference with a person's liberty by physical force or a show of authority that would cause a reasonable person consciously to submit." ${ }^{, 54}$ Since the decedent was unconscious, the court found that no Fourth Amendment violation existed because the patient necessarily "could not perceive any restraint on his liberty or otherwise feel compelled to submit to a governmental show of force."s5

In another case, Davidson v. City of Jacksonville, ${ }^{56}$ EMS and fire personnel restrained an uncooperative patient suffering a hypoglycemic episode (low blood sugar), in order to check his vital signs, establish an IV line, and administer medicine used to treat low blood sugar. ${ }^{57}$ After securing his hands with handcuffs, tying his ankles together, and connecting the two restraints with a bandage, they carried him by his arms and legs to the stretcher located at the

48. Id. at 1203 .

49. U.S. CONST. amend. IV.

50. "The overarching prerequisite for custody is an affirmative act by the state that restrains the ability of an individual to act on his own behalf." Jackson v. Schultz, 429 F.3d 586, 590 (6th Cir. 2005). "The court has never held that one merely placed in an ambulance is in custody." Id.

51. U.S. CoNST. amend. IV.

52. 486 F.3d 217 (6th Cir. 2007).

53. Id. at 220.

54. Id.

55. Id. at 221.

56. 359 F. Supp. 2d 1291 (M.D. Fla. 2005).

57. Id. 
front door. ${ }^{58}$ The patient's mid-section was unsupported while being carried; he was subsequently diagnosed with a herniated disc and suffered a permanent disability as a result. ${ }^{59}$ The court rejected the plaintiff's Fourth Amendment claim on grounds similar to those in Peete, stating: "there is no evidence that Mr. Davidson was aware of, or was mentally present in, the situation. Instead, it seems that any 'resistance' was merely a result of the diabetic episode . . . which Mr. Davidson was experiencing."60 The court held that the Fourth Amendment was inapplicable "given the lack of refusal on Mr. Davidson's part.",61

Indeed, the only viable Fourth Amendment claims against EMTs, when the EMTs are acting without law enforcement intervention or intent, are those in which a patient was capable of refusing treatment or transport, did refuse, but was transported or treated nonetheless. In Green $v$. City of New York, ${ }^{62}$ the patient-plaintiff suffered from Lou Gehrig's disease, required a mechanical ventilator to breathe, and if the mechanical ventilator malfunctioned, family members had to perform manual ventilation. ${ }^{63}$ One afternoon, after the patientplaintiff's mechanical ventilator failed, his family called 911 and initiated manual ventilation. ${ }^{64}$ By the time EMTs arrived, the patient-plaintiff was alert and oriented, and was able to non-verbally communicate-by blinking his eyes and using a computer - that he did not want to be transported to the hospital. ${ }^{65}$ The emergency medical personnel on scene transported the patient-plaintiff anyway. ${ }^{66}$ The court held that seizing and transporting a competent adult for treatment is a violation of the Fourth Amendment, unless he presents a danger to himself or others. ${ }^{67}$

As gleaned from these cases, a Fourth Amendment claim against EMTs based solely on flawed medical care is not viable, because the EMTs are "not acting to enforce the law, deter or incarcerate." ${ }^{\text {"68 }}$ As in Green, a patient with

58. Id.

59. Id. at 1294 .

60. Id. at 1295 .

61. Id. This holding begs the question of what is sufficient to constitute a "refusal." Express consent is required from every conscious, mentally-competent patient of legal age before rendering treatment. See NaT'L Highway TransP. SAFETY ADMIN., U.S. DeP'T OF TranSP., EMERGENCY MED. TECHNICIAN-BASIC: NAT'L STANDARD CURRICULUM 68 (1994), available at http://www.nhtsa.dot.gov/people/injury/ems/pub/emtbnsc.pdf [hereinafter EMT-BASIC: NATIONAL STANDARD CURRICULUM] ; see also Jon Belding, Patient Refusal: What to Do When Medical Treatment and Transport Are Rejected, 31 no. 5 J. EMERGENCY MED. SERVICES. 116, 116-17 (2006); IND. CODE §§ 16-36-1-3-16-36-1-4 (1993). Implied consent is given when an unconscious patient requires emergency medical care, and such consent is based on the assumption that the unconscious patient would consent to emergency care if he was conscious. See EMT- BASIC: NATIONAL STANDARD CURRICULUM, supra at 68; see also Belding, supra at 5.

62. 465 F.3d 65 (2d Cir. 2006).

63. Id. at 69.

64. Id. at 70 .

65. Id. at 71 .

66. Id. at 73 .

67. Id. at 83 .

68. Peete, 486 F.3d at 222. 
the capacity to refuse consent may have a successful claim against EMTs who disregard such a refusal; however, those claims can be distinguished as dealing with the forcible seizure of a person by a government official, rather than dealing with medical care.

\section{B. The Eighth Amendment}

Plaintiffs may also allege violations of the Eighth Amendment for care rendered in the field. The Eighth Amendment prohibits, among other things, the inflicting of cruel and unusual punishment. ${ }^{69}$ Liability under the Eighth Amendment must necessarily be preceded by a determination that the patient is in custody under the Fourth Amendment. This is because the "[g]overnment generally has no constitutional duty to provide rescue services to its citizens, and if it does provide such services, it has no constitutional duty to provide competent services to people not in its custody." Government must provide rescue services to people in its custody. The subsequent inquiry is what standard of care must be provided.

In Salazar v. Chicago, ${ }^{71}$ the decedent-plaintiff drove after drinking excessively, and then ran into a parking meter and the front of a restaurant. ${ }^{72}$ Paramedics were the first on-scene; they took the decedent-plaintiff's vital signs and began palpating his body for injuries, at which time he refused further examination. ${ }^{73}$ The police arrived shortly thereafter and both the police and paramedics attributed the decedent-plaintiff's disorientated behavior to his intoxication. ${ }^{74}$ The paramedics left, leaving the decedent-plaintiff with the police who subsequently arrested him. ${ }^{75} \mathrm{He}$ was taken to the police station that night and died the next afternoon from a traumatic liver laceration, a condition which had no obvious external symptoms. ${ }^{76}$ At trial, when establishing the standard applicable to their actions, the paramedics conceded that the decedent-plaintiff should have been treated as a pre-trial detainee. ${ }^{77}$

The court then held that the Eighth Amendment imposes liability on the paramedics only if their behavior "reflects complete indifference to risk- when the actor does not care whether the other person lives or dies, despite knowing that there is a significant risk of death."78 As applied to the behavior of the paramedics in Salazar, "[p]erhaps [they] should have done more for Salazar, and perhaps their failure to do more was either negligent or (doubtedly) grossly neg-

69. U.S. Const. amend. VIII.

70. Salazar v. City of Chicago, 940 F.2d 235, 237 (7th Cir. 1991).

71. Id.

72. Id. at 234 .

73. Id. at 235.

74. Id. at 236.

75. Id.

76. Salazar, 940 F.2d at 236.

77. Id. at 237.

78. Id. at 238 (quoting Archie v. City of Racine, 847 F.2d 1211, 1219 (7th Cir. 1988)). 
ligent. But [their] actions do not evidence the complete indifference to Salazar's well-being that constitutes deliberate indifference." 79 The Seventh Circuit defined "deliberate indifference" as conduct that is intentional or criminally reckless. ${ }^{80}$ This definition is based on a consideration of what constitutes "punishment," as the Eighth Amendment's prohibitions speak only to cruel and unusual punishment, and "[a]ny state of mind short of criminal recklessness does not import danger so great that knowledge of the danger and thus, intent to inflict it, can be inferred." $" 81$

In Peete, the decedent-plaintiff, who had an epileptic episode and died after being physically restrained, argued that the behavior of the EMTs manifested a deliberate indifference ${ }^{82}$ to serious medical needs, in violation of the Eighth Amendment. ${ }^{83}$ After the patient's Fourth Amendment argument failed, ${ }^{84}$ the court rejected any argument rooted in Eighth Amendment protections:

where the purpose is to render solicited aid in an emergency rather than to enforce the law, punish, deter, or incarcerate, there is no federal case authority creating a constitutional liability for the negligence, deliberate indifference, and incompetence alleged in the instant case. The Eighth Amendment "Cruel and Unusual Punishment" Clause raising a "deliberate indifference" standard does not apply here because Becerra was not incarcerated and the purpose of the alleged wrong was not punishment. ${ }^{85}$

This case demonstrates that an Eighth Amendment violation occurs only if a patient is in custody at the time of receiving medical care, and the care rendered by the EMT shows such complete indifference to the patient's well-being that it constitutes deliberate indifference. As this standard of care requires criminal recklessness, mere negligence by an EMT, even gross negligence, is insufficient to impose liability under the Eighth Amendment.

\section{The Fourteenth Amendment}

A cursory glance at federal case law renders the impression that the most

79. Salazar, 940 F.2d at 242.

80. Id. at 238; see also Archie, 847 F.2d at 1218.

81. Salazar, 940 F.2d at 239 (internal quotation marks omitted).

82. Estelle v. Gamble, 429 U.S. 97, 104 (1976) ("[D]eliberate indifference to serious medical needs of prisoners constitutes the unnecessary and wanton infliction of pain [...] proscribed by the Eighth Amendment")(internal citations omitted).

83. Peete, 486 F.3d at 221.

84. See Part III.A, infra.

85. Peete, 486 F.3d at 221. 
commonly alleged $\$ 1983$ violations involving EMTs are violations of Fourteenth Amendment protections, specifically the Due Process Clause. ${ }^{86}$ The Due Process Clause provides that the Government shall not "deprive any person of life, liberty, or property without due process of law.",87 Just as the Eighth Amendment speaks to the standard of care owed to a patient in state custody, the Due Process Clause imposes the standard of care on EMTs providing emergency medical services to the general public. According to the Supreme Court, the Due Process Clause "forbids the State itself to deprive individuals of life, liberty, or property without 'due process of law,' but its language cannot fairly be extended to impose an affirmative obligation on the State to ensure that those interests are not harmed through other means." 88 As a charter of negative liberties, the Constitution seeks "to protect Americans from oppression by state government, not to secure them basic governmental services." 89 Expanding the Due Process Clause to include a right to government services "would turn the clause on its head. It would change it from a protection against coercion by state government to a command that the state use its taxing power to coerce some of its citizens to provide services to others." 90

The general rule is that "there is no federal constitutional right to rescue services, competent or otherwise. Moreover, because the Due Process Clause does not require the State to provide rescue services, it [does not] ... place an affirmative obligation on the State to provide competent rescue services if it chooses to provide them."91 Even when a municipality establishes itself as the primary provider of some service, it does not acquire a continuing constitutional duty to provide the service, since "such a position 'would open the way for scrutiny by the federal courts of virtually every municipal decision to reallocate protective resources." $" 92$

Accordingly, the standard imposed by the Fourteenth Amendment on governmental actors is particularly low: state action must not be "arbitrary, or conscience shocking, in a constitutional sense." shocking" test determines liability for abusive executive action. ${ }^{94}$ In evaluating constitutional claims, "[w]hether something less than intentional conduct 'shocks the conscience' varies depending on the context of the alleged viola-

86. U.S. CoNST. amend. XIV, $\S 1$.

87. Id.

88. DeShaney v. Winnebago County Dep't. of Social Servs., 489 U.S. 189, 195 (1989).

89. Jackson v. City of Joliet, 715 F.2d 1200, 1203 (7th Cir. 1983).

90. Id. at 1203-04.

91. Brown v. Pennsylvania, 318 F.3d 473, 478 (3d Cir. 2003) (citing, inter alia, Salazar, 940 F.2d at 237); see also Culver-Union Twp. Ambulance Serv. v. Steindler, 629 N.E.2d 1231, 1234 (Ind. 1994) ("There is no constitutional right to be rescued by the government, and inept rescue is not a cognizable theory for due process liability under $\$ 1983$.").

92. Wideman v. Shallowford Cmty. Hosp., 826 F.2d 1030, 1036 (11th Cir. 1987) (citing Jackson v. Byrne, 738 F.2d 1443, 1447 (7th Cir. 1984)).

93. Christensen v. County of Boone, 483 F.3d 454, 462 (7th Cir. 2007).

94. Id. at 462. 
tion." 95 This standard is sufficiently low that constitutional liability for negligent medical treatment rendered by EMTs does not come within its scope. ${ }^{96}$

Although some federal holdings could be read to narrow or refine the application of this standard, negligent prehospital care still falls outside of liability even under the narrowed applications. In Brown, the Third Circuit held that "the 'shocks the conscience' standard should apply in all substantive due process cases if the state actor had to act with urgency."97 The court applied the standard to an allegation of incompetence against emergency medical personnel. ${ }^{98}$ In Ziccardi v. Philadelphia,${ }^{99}$ the court applied a substantive due process analysis to the conduct of two paramedics accused of moving a man who fell and subsequently became paralyzed. ${ }^{100}$ The court held that a due process violation required "proof that the [paramedics] consciously disregarded, not just a substantial risk, but a great risk that serious harm would result if, knowing [the patient] was seriously injured, they moved [him] without support for his back and neck." 101

\section{CIVIL LIABILITY STATUTES}

As the preceding section demonstrates, negligent medical care by EMTs is an insufficient ground upon which to base a constitutional claim under $\S 1983$. Thus, other provisions governing the standard of care must drive liability for Indiana's prehospital providers based on negligent medical care. This section introduces those provisions.

\section{A. Statutory Provisions for Civil Liability in Indiana and Surrounding States}

\section{Indiana}

In Indiana, the standard for civil liability for EMS providers is expressly provided for by statute. With regard to BLS providers, "[a] certified emergency medical technician $[\ldots$.$] who provides emergency medical services to an emer-$ gency patient is not liable for an act or omission in providing those services

95. Id.

96. The U.S. Supreme Court has noted that "[i]t should not be surprising that the constitutional concept of conscience shocking duplicates no traditional category of common-law fault, but rather points clearly away from liability, or clearly toward it, only at the ends of the tort law's spectrum of culpability. Thus, we have made it clear that the due process guarantee does not entail a body of constitutional law imposing liability whenever someone cloaked with state authority causes harm." County of Sacramento v. Lewis, 523 U.S. 833, 848 (1998).

97. Brown, 318 F.3d at 480

98. Id.

99. 288 F.3d 57 (3d Cir. 2002).

100. Id. at 57 .

101. Id. at 66 . 
unless the act or omission constitutes negligence or willful misconduct."102 For ALS providers,

[a]n act or omission of a paramedic or an emergency medical technician-intermediate done or omitted in good faith while providing advanced life support to a patient or trauma victim does not impose liability upon the paramedic or emergency medical technician-intermediate [...] if the advanced life support is provided: (1) in connection with an emergency; (2) in good faith; and (3) under the written or oral direction of a licensed physician; unless the act or omission was a result of negligence or willful misconduct. ${ }^{103}$

Though the language of the statutes differs, both provide for liability for acts constituting ordinary negligence. The language of the statute itself, however, is somewhat anomalous. A fundamental principle of common law is the imposition of a duty of reasonable care, with resulting liability for negligent acts. ${ }^{104}$ A statute imposing liability in the exact situation where the default common law already imposes it (e.g. a statute imposing liability for negligence) seems unnecessarily duplicative. Additionally, expressly imposing liability for "negligence" and "willful misconduct" in the same statute creates confusion because the two represent opposing behavioral extremes as it relates to a breach of the duty of care. A more logical progression would be to include negligence, gross negligence, and willful or wanton misconduct. ${ }^{105}$

Generally speaking, liability for ordinary negligence is rare for EMS providers because most states have statutes insulating EMTs from this type of liability. ${ }^{106}$ Other states without specific statutes granting some sort of immunity to EMTs apply the protection of sovereign immunity to EMTs who are government employees or apply the provisions of the jurisdiction's "Good Samaritan" statutes to professional rescuers. ${ }^{107}$ As the following statutes demonstrate, all of the states surrounding Indiana provide immunity from liability for, at the very least, acts of ordinary negligence by EMTs.

102. IND. CODE § 16-31-6-1(a) (2008).

103. IND. CODE § 16-31-6-3 (2008).

104. RESTATEMENT (THIRD) OF TORTS $\S 7$ (2005) ("An actor ordinarily has a duty to exercise reasonable care when the actor's conduct creates a risk of physical harm.").

105. The EMT civil liability statutes of Michigan, Illinois, Ohio, and Kentucky, provided infra, show a more natural progression of behavioral prohibitions, beginning with gross negligence and proceeding to willful or wanton misconduct.

106. See generally Frank J. Wozniak, Annotation, Liability for Negligence of Ambulance Attendants, Emergency Medical Technicians, and the Like, Rendering Emergency Medical Care Outside Hospital, 16 A.L.R. 5th 605 (1993).

107. Id. at 605. 
2. Michigan

Unless an act or omission is the result of gross negligence or willful misconduct, the acts or omissions of [an ...] emergency medical technician [or] paramedic, [...] do not impose liability in the treatment of a patient on those individuals. ${ }^{108}$

\section{Illinois}

Any person, agency or governmental body certified, licensed or authorized pursuant to [the EMS] Act or rules thereunder, who in good faith provides emergency or non-emergency medical services during a Department approved training course, in the normal course of conducting their duties, or in an emergency, shall not be civilly liable as a result of their acts or omissions in providing such services unless such acts or omissions $[\ldots]$ constitute willful and wanton misconduct. ${ }^{109}$

Illinois courts have done a particularly notable job of making clear the policies driving statutory grants of immunity:

[B]y enactment of the immunity provision, the legislature intended to encourage emergency response by trained medical personnel without risk of malpractice liability for every bad outcome or unfortunate occurrence. Emergency situations are often fraught with tension, confusion, and as here, difficult physical locations for giving medical care. Emergency personnel must not be afraid to do whatever they can under less than ideal circumstances. ${ }^{110}$

The court further notes:

[t]he threat of impending liability [. . .] is detrimental to the ability of medical personnel to effectively perform their duties. Medical personnel work under extreme circumstances and must be able to make life-saving decisions. ... [Liability] would not only impede the EMTs' 
ability to render effective medical care, but it would also deter many from entering this profession and working under such circumstances. ${ }^{111}$

\section{Ohio}

A first responder, emergency medical technician-basic, emergency medical technician-intermediate, or emergency medical technician-paramedic is not liable in damages in a civil action for injury, death, or loss to person or property resulting from the individual's administration of emergency medical services, unless the services are administered in a manner that constitutes willful or wanton misconduct. ${ }^{112}$

\section{Kentucky}

No [...] person certified as an emergency medical technician by the Kentucky Cabinet for Health and Family Services $[. .$.$] shall be liable in civil damages for admi-$ nistering emergency care or treatment at the scene of an emergency outside of a hospital, doctor's office, or other place having proper medical equipment excluding house calls, for acts performed at the scene of such emergency, unless such acts constitute willful or wanton misconduct. $^{113}$

\section{B. States Providing for Liability for Ordinary Negligence}

Though some other states also allow for civil liability for acts of ordinary negligence by EMTs, none have done so as explicitly as Indiana has in § 16-316-1. The routes taken by other states to impose an ordinary negligence standard vary, but generally involve invoking exemptions from other types of immunity protections. Tennessee courts, for example, have concluded that EMTs are "health care practitioners" and are thus ineligible for the immunity protections provided by the state's Governmental Tort Liability Act. ${ }^{114}$

Kansas courts took a different route but arrived at the same conclusion-

111. Brock v. Anderson Rd. Ass'n, 703 N.E.2d 568, 571 (IIl. App. Ct. 1998).

112. OHIo ReV. CoDE ANN. $\$ 4765.49$ (West 2007).

113. KY. ReV. STAT. ANN. $\$ 411.148$ (West 2005).

114. Mooney v. Sneed, 30 S.W.3d 304, 308 (Tenn. 2000). In this regard, the language of Indiana's governmental immunity statute, the Indiana Tort Claims Act ("ITCA"), is similar to that of Tennessee. The ITCA expressly withholds immunity protections for "medical care" rendered by government officials by categorizing it as a "ministerial act" ineligible for immunity. IND. CODE § 34-13-3-3(7) (2006). 
liability for ordinary negligence. In James $v$. Rowe, ${ }^{115}$ the court concluded that both statutory construction and legislative history supported an interpretation of the Kansas Good Samaritan Act that applied its immunity protections only to those who "happen across an emergency outside the normal course of their work and otherwise have no duty to assist,"116 thus rendering the statute inapplicable to EMTs responding to calls while on-duty.

\section{Application of Ordinary Negligence Standard to EMTs}

Since Indiana law provides for civil liability for EMTs who act negligently, a brief consideration of the elements of negligence and their application to the actions or omissions of EMS providers is warranted. An action for negligence must establish three elements:

(1) a duty on the part of the defendant to conform his conduct to a standard of care arising from his relationship with the plaintiff, (2) a failure of the defendant to conform his conduct to the requisite standard of care required by the relationship, and (3) an injury to the plaintiff proximately caused by the breach. ${ }^{117}$

The first element, a duty to act, is usually undisputed in a negligence action against an EMS provider because "[i]f the [EMT] responds to a call with a designated agency, the duty already exists [...] [I]f [the EMT's] agency is the EMS service responsible in a particular location and [the EMT] is on duty, there is an obligation to provide service to anyone who requests assistance."118 119 The second element, a breach of the duty to act or deviation from the standard of care, "asks what a reasonably prudent person would do in the same situation." 120 An EMT "must exercise that degree of care, skill, and proficiency exercised by reasonably careful, skillful, and prudent practitioners in the same class acting under the same or similar circumstances."121 In attempting to define the standard of care applicable to EMTs, the fact-finder may consider "[g]enerally accepted and recognized textbooks," "[t]he expected level of care provided by like providers in the community," "[s]tate and local protocols and national Department of Transportation curricula," and "[ $t]$ he agency's own op-

115. 674 F.Supp. 332 (D. Kan. 1987) (applying Kansas law).

116. Id. at 333. See Part V.B.2, infra, for a consideration of Indiana's Good Samaritan Law.

117. Webb v. Jarvis, 575 N.E.2d 992, 995 (Ind. 1991) (citations omitted).

118. COHN \& AZZARA, supra note 21 , at 9.

119. See Part V.B.1, infra, for a discussion of the immunity available to off-duty EMTs under the Good Samaritan Act.

120. COHN \& AZZARA, supra note 21, at 12.

121. Dughaish ex rel. Dughaish v. Cobb, 729 N.E.2d 159, 164 (Ind. Ct. App. 2000). 
erating procedures, policies and rules."122 In medical malpractice, the applicable standard of care is often fiercely contended as it bears heavily on whether liability will stand and experts are generally used by both parties to identify the standard of care applicable to the circumstances at issue. ${ }^{123}$

The final element, proximate cause, can also be quite complicated in medical malpractice actions, especially those alleging malpractice in the prehospital setting. In Indiana, the plaintiff must prove: 1) that "the injury would not have occurred without the defendant's negligent act or omission;"124 and, 2) "the injury was a natural and probable consequence of the negligent act, which, in the light of the attending circumstances, could have been reasonably foreseen or anticipated." 125 The EMT's conduct "must have set in motion a chain of circumstances which in natural and continuous sequence lead to the resulting injury."126 Many patients cared for by EMTs are severely injured or suffering from a significant illness before an EMT even arrives - it is "emergency" medical services after all. Even if there is clear negligence on the part of the EMT, it may not be the proximate cause of the plaintiff's injuries and may not be a basis for recovery.

\section{THE INDIANA MEDICAL MALPRACTICE ACT}

\section{A. Generally}

The Indiana Medical Malpractice Act (the "Act") was enacted on April 17,1975 . $^{127}$ The legislation was passed to help ease the strain placed on health care professionals seeking professional insurance, a strain that had a detrimental affect on the availability of health care services in Indiana. ${ }^{128}$ The Act applies to EMTs if they qualify since the Act defines "healthcare provider" to include a "paramedic, emergency medical technician-intermediate, emergency medical technician-basic advanced, or emergency medical technician."129 To qualify under the Act, "the health care provider or the health care provider's insurance

122. COHN \& AZZARA, supra note 21 , at 12 .

123. N. GENELl LEE, Legal CONCEPTS AND IsSUES IN EMERGENCY CARE 214 (W.B. Saunders Company 2001).

124. Perez v. Bakel, 862 N.E.2d 289, 293 (Ind. Ct. App. 2007).

125. Dughaish, 729 N.E.2d at 164; see also Perez, 862 N.E.2d at 293 ("The second component of proximate cause is the scope of liability, which turns largely on whether the injury is a natural and probable consequence that in the light of the circumstances should have been foreseen or anticipated. Under this doctrine, liability may not be imposed on an original negligent actor who sets into motion a chain of events if the ultimate injury was not reasonably foreseeable as the natural and probable consequence of the act or omission." (internal quotation marks and citations omitted)).

126. Dughaish, 729 N.E.2d at 164.

127. 23 Ind. Prac. $\$ 11.1$ (citing IND. Code ANN. § 16-9.5-1-1 (West 1975)).

128. Id. (citing Johnson v. St. Vincent Hosp., Inc., 404 N.E.2d 585, 590 (Ind. 1980)).

129. IND. CODE § 34-18-2-14 (2003). 
carrier shall: (1) cause to be filed with the commissioner proof of financial responsibility established under IC 34-18-4; and (2) pay the surcharge assessed on all health care providers under IC 34-18-5." $"$ An additional provision of the Act of particular importance when considering EMS providers is that "[a] claim against a governmental entity or an employee of a governmental entity based on an occurrence of malpractice is governed exclusively by this article if the governmental entity or employee is qualified under this article."131 132

Under the reforms contained in the Act, any potential medical malpractice claim against a health care provider who qualifies under the Act must be presented to a medical review panel if the plaintiff claims damages in excess of $\$ 15,000$. $^{133}$ The medical panel consists of one attorney and three health care providers, ${ }^{134}$ two of whom must be members of the defendant's profession. ${ }^{135}$ The medical panel considers evidence submitted by both parties, including "medical charts, x-rays, lab tests, excerpts of treatises, [and] depositions of witnesses including parties." 136 Then, the panel expresses an expert opinion "as to whether or not the evidence supports the conclusion that the defendant or defendants acted or failed to act within the appropriate standards of care as charged in the complaint." 137 An opinion unfavorable to the plaintiff does not preclude filing a medical malpractice claim in court, but the opinion is admissible as evidence in subsequent litigation and members of the medical review panel may be called as witnesses by either party. ${ }^{138}$ A plaintiff may file his claim in court while the proposed complaint is being considered by the medical review panel, but the complaint must not contain information that would allow a third party to identify the defendant provider, and the claimant may not pursue the action beyond setting a date for trial until the medical panel has concluded its review. ${ }^{139}$

In light of the provisions discussed above, the protection elements of the Act are clear: the medical review panel and the expert opinion it expresses serve as a potential front-end limitation on frivolous lawsuits, and the Act caps damage awards as a back-end limitation on the impact of exorbitant damage

130. §34-18-3-2 (1998).

131. §34-18-3-4(c) (1998); see also Jeffries v. Clark Mem'l Hosp., 832 N.E.2d 571, 573 (Ind. Ct. App. 2005) ("[A] malpractice claim brought against a governmental entity is governed solely by the Medical Malpractice Act").

132. It is worth noting that the defense of sovereign immunity is unavailable to municipally employed EMTs since the ITCA defines medical care as ministerial, which precludes it from ITCA protections: in a tort claim, "[a] governmental entity or an employee acting within the scope of the employee's employment is not liable if a loss results from [...] [t]he performance of a discretionary function; however, the provision of medical or optical care [...] shall be considered as a ministerial act." $\$ 34-13-3-3(7)(2006)$.

133. § 34-18-10 et. seq. (1998); §34-18-8-6 (1998).

134. IND. CODE § 34-18-10-3 (1998).

135. §34-18-10-8 (1998).

136. §34-18-10-17 (1998).

137. §34-18-10-22(1998).

138. § 34-18-10-23(1998).

139. §34-18-8-7 (1998). 
awards on health care providers. The total damage award for an act of malpractice occurring after June 30,1999 is $\$ 1,250,000,{ }^{140}$ of which the health care provider is liable for only $\$ 250,000{ }^{141}$ Damages in excess of $\$ 250,000$ are paid to the plaintiff out of the Patient's Compensation Fund ("PCF"). ${ }^{142}$ The PCF is comprised of the annual surcharge paid by all health care providers who participate under the Act. ${ }^{143}$ The limitation on damages has survived a constitutional challenge alleging that it denies due process of law by imposing an irrebuttable presumption that the plaintiff's damages cannot exceed the limitation and precluding him from proving otherwise. ${ }^{144}$ According to the court, the limitation is not a denial of due process because "[i]t is not a presumption which prevents recovery of more than that amount, but the policy of the law in the statute."145

The Act is designed to curtail liability for medical malpractice, not to expand it. ${ }^{146}$ Additionally, it does not create substantive rights or new causes of action; it requires that medical malpractice claims that are recognized under tort law and applicable statutory provisions be subjected to the procedures of the Act. ${ }^{147}$ "[T] $]$ he Act only lays out the procedural mechanism for disposing of claims of medical malpractice; it does not alter the substantive law to be applied in the adjudication of those claims on the merits." ${ }^{\text {"148 }}$ Thus, the litigation stage of a proceeding against a health care provider that is qualified under the Act and one that is not are the same in all respects save two: the potential admission into evidence of the expert opinion from the medical panel and the available damages. ${ }^{149}$

\section{B. The Patient's Compensation Fund}

The PCF is administered by the Indiana Department of Insurance ("IDOI"). ${ }^{150}$ The IDOI website provides a balance sheet and claim synopsis

140. $\S 34-18-14-3(\mathrm{a})(3)(1998)$.

141. \$34-18-14-3(b) (1998).

142. §34-18-14-3(c)(1998).

143. § 34-18-6-1 (1998).

144. Johnson, 404 N.E.2d at 599, overruled on other grounds by In re Stephens, 867 N.E.2d 148 (Ind. 2007); see St. Anthony Med. Ctr., Inc. v. Smith, 592 N.E.2d 732, 739 (Ind. Ct. App. 1992) (Plaintiff "contends that the Act violates the due process clause of the United States and the State of Indiana's Constitution; violates the right to a jury trial; is an irrebuttable presumption; violates the Equal Protection and special legislation clauses; and, denies the right of access to the courts and the constitutional rights to a full and complete remedy. Our supreme court has previously addressed these issues in Johnson ... and we are bound by its finding that the Act is constitutional.")

145. Johnson, 404 N.E.2d at 600.

146. Chamberlain v. Walpole, 822 N.E.2d 959, 963 (Ind. 2005) (citing Johnson, 404 N.E.2d at 589).

147. Atterholt v. Robinson, 872 N.E.2d 633, 640 (Ind. Ct. App. 2007).

148. Cacdac v. West, 705 N.E.2d 506, 510 (Ind. Ct. App. 1999).

149. IND. CODE § 34-18-1-1 et seq (1998).

150. See generally IDOI: Healthcare Providers, Indiana Dept. of Ins., available at 
covering the financial attributes of the PCF from 1975-2007. ${ }^{151}$ With little deviation, the judgment amounts paid from the PCF per year have consistently increased: from $\$ 425,000$ in 1978 to $\$ 94,589,261$ in $2007 .^{152}$ Since its inception in 1975, the PCF balance has never run a deficit. ${ }^{153}$ In 2007 , the PCF balance was $\$ 152,268,523 .{ }^{154}$ In 2006 and 2007 , payments into the PCF exceeded payments out of the PCF by $\$ 43,545,882$ and $\$ 56,963,864$, respectively. ${ }^{155}$ Overall, the statistics from the PCF report indicate that the financial integrity of the PCF is secure for the foreseeable future. ${ }^{156}$

\section{THE POLICY CONSIDERATIONS DRIVING IMMUNITY}

The position of this Note is that some immunity protections are warranted for Indiana EMS providers. The following are some of the policy considerations in support of the proposed immunity.

\section{A. The State of EMS in Indiana}

In September 2007, a Purdue University research team published the results of the 2007 Indiana Emergency Medical Services Survey. ${ }^{157}$ The survey was funded by the Indiana State Department of Health and the U.S. Department of Health and Human Services. ${ }^{158}$ The survey was administered to a sample of Indiana EMS personnel holding at least an EMT-Basic certificate. ${ }^{159}$ The results paint a picture of an EMS system with a number of potentially problematic attributes that may bear on the appropriateness (or inappropriateness) of the current civil liability scheme for Indiana's EMS providers.

The average survey respondent was forty years old; $72.3 \%$ were male, $72.7 \%$ were married, and $60.7 \%$ had children at home. ${ }^{160}$ Overall, vacancy rates are high: twenty percent of EMT-Basic and twenty-five percent of EMTParamedic positions are unfilled. ${ }^{161}$ Over ninety percent of both paid departments and volunteer departments report that hiring is either "Very Difficult" or

http://www.in. gov/idoi/2385.htm.

151. INDIANA DEP'T. OF INS., INDIANA PATIENT'S COMPENSATION FUND: ANNUAL REPORT FOR 2007, http://www.in.gov/idoi/files/pcf_annual_report_2007.pdf(last visited Jul. 7, 2008).

152. Id. at 2. From 1975-1977, no judgments were paid out of the PCF. Id.

153. Id.

154. Id.

155. Id.

156. This Note does not address the propriety of EMS participation under the Act. The Act is covered for the purpose of considering its utility as a potential indemnification device for EMS providers. See discussion, supra Section VI.

157. George Avery, Purdue University, 2007 Indiana EMERgency Med. Serv. SURVEY: CHARTBOOK (2007) [hereinafter EMS SURVEY: CHARTBOOK]; GEORGE AVERY, PURDUE UNIVERSITY, INDIANA EMERGENCY MED. SERV. NEEDS ASSESSMENT: WORKFORCE AND TRAINING ISSUES SURVEY REPORT (2007) [hereinafter EMS SURVEY: REPORT].

158. EMS SURVEY: CHARTBOOK, supra note 157, at 1.

159. EMS SURVEY: REPORT, supra note 157 , at 6.

160. Id. at 7 .

161. Id. 
"Somewhat Difficult." staffed entirely with volunteers. ${ }^{163}$ Over two-thirds of EMS organizations are affiliated with fire departments, and another $18.6 \%$ are hospital-based. ${ }^{164}$ Those who administered the survey offered the most significant findings regarding EMS personnel:

Evidence exists of a shortage of EMS personnel in Indiana due to high vacancy rates. This is particularly acute in volunteer organizations, which report the greatest difficulty in recruiting EMS personnel. Paid EMS personnel work on average significantly more than a standard 40 hour week, and high percentages of EMS personnel add a second job. Because excessive working hours have been linked to low quality healthcare, this may indicate potential problems with the quality of EMS care. $^{165}$

Additionally, the report concludes that "[t]he training environment, both in terms of initial and continuing training, is so varied that it cannot realistically be considered a "system,", "166 and that "[s]elf-assessment of preparedness levels by EMS personnel reveals that the EMS system in rural areas is likely to be less prepared and capable than in urban areas." tend to leave their EMS positions within the next year, 9.1\% cited "legal liability issues" as one of their reasons. ${ }^{168}$

\section{B. Other Statutory Grants of Immunity}

\section{Indiana Code Section 16-31-6-4: Immunity in Disaster Emergency}

Immunity from liability for ordinary negligence is not foreign to the Indiana Code. In the event of a disaster emergency resulting from terrorism, ${ }^{169}$ EMTs in Indiana are not liable for acts or omissions in the provision of medical care that constitute ordinary negligence. ${ }^{170}$ At first glance, granting immunity in these situations seems warranted, whereas general immunity does not. The reality, however, is otherwise. The differences between providing EMS care

162. EMS SURVEY: CHARTBOOK, supra note 157, at 16 tbl. 2.2.1.

163. EMS SURVEY: REPORT, supra note 157 , at 6.

164. Id. at 7.

165. Id. at 3 .

166. Id. at 13.

167. Id. at 14.

168. EMS SURVEY: CHARTBOOK, supra note 157, at 102.

169. The Governor's disaster emergency declaration is governed by $\S 10-14-3-12$ of the Indiana Code. See IND. CodE ANN. § 10-14-3-12 (2004).

170. IND. CODE $\S 16-31-6-4$ (2004). 
during a disaster and providing EMS care under "ordinary" circumstances are insufficient to warrant disparate treatment between the two. Emergency medical care, regardless of when it is rendered, is a demanding and rigorous exercise in patient management, diagnosis, treatment, and transportation. In the same EMS survey quoted in the preceding section of this Note, over eighteen percent of Indiana EMTs planning to leave EMS within the next year cited "EMSrelated stress" as a reason. ${ }^{171}$ Another eighteen percent cited "[p]hysical demands of EMS work" as a reason. ${ }^{172}$ There is no readily distinguishable difference - at least one warranting separate immunity standards - between an EMT rendering medical care at the site of an explosion caused by a gas leak and a site where explosives were placed intentionally.

\title{
2. Indiana Code Section 34-30-12-1(b): Good Samaritan Law
}

Another immunity provision in the Indiana Code relevant to the consideration of immunity for EMTs is the Good Samaritan Law. ${ }^{173}$ The law provides that:

\begin{abstract}
a person who comes upon the scene of an emergency or accident or is summoned to the scene of an emergency or accident and, in good faith, gratuitously renders emergency care at the scene of the emergency or accident is immune from civil liability for any personal injury that results from: (1) any act or omission by the person in rendering the emergency care; or (2) any act or failure to act to provide or arrange for further medical treatment or care for the injured person; except for acts or omissions amounting to gross negligence or willful or wanton misconduct. ${ }^{174}$
\end{abstract}

Beckerman v. Gordon marked the first opportunity for an Indiana court to analyze the provisions of the Good Samaritan Law. ${ }^{175}$ Even though that case interpreted language that has subsequently been repealed by the Indiana General Assembly, the principles of statutory construction it lays out regarding the Good Samaritan Law are instructive in considering the statute in its current manifestation. First, "[w] hen construing statutes in derogation of the common law [as the Good Samaritan Law is], the statute is strictly construed against limitations on a claimant's right to bring suit." 176 Further, "when such a statute is

171. EMS SURVEY: CHARTBOOK, supra note 157, at 102.

172. Id.

173. IND. CODE § 34-30-12-1 (2006).

174. Id.

175. Beckerman v. Gordon, 614 N.E.2d 610, 612 (Ind. App. Ct. 1993).

176. Id. (citing Tittle v. Mahan, 582 N.E.2d 796 (Ind. 1991)). 
enacted, [the court] presume[s] the legislature was aware of the common law and that it did not intend to make any changes beyond those contained in the express terms or unmistakable implications of the statute."177

With the court's strict construction mandate in mind, the relevant inquiry is the scope of immunity provided to EMTs under Indiana's current Good Samaritan Law. The civil liability statute providing that an EMT "who provides emergency medical services to an emergency patient is not liable for an act or omission in providing those services unless the act or omission constitutes negligence or willful misconduct" ${ }^{\text {178 }}$ makes no effort to distinguish between emergency care provided by on-duty and off-duty EMTs. Therefore, the Good Samaritan Law arguably cannot be used to immunize an off-duty EMT from liability for ordinary negligence in rendering emergency care at the scene of an emergency. To repeat the court's charge in Beckerman: in interpreting the Good Samaritan Law, the court will "presume the legislature was aware of the common law and that it did not intend to make any changes beyond those contained in the express terms or unmistakable implications of the statute."179 If the court presumes the legislature is aware of the common law, it most certainly presumes the legislature is aware of legislation, or statutory law. Section 1631-6-1 explicitly and unambiguously levies civil liability against negligent EMTs. The Good Samaritan Law fails to expressly or unmistakably set aside this express statutory liability of EMTs, on-duty or off-duty.

Here, the anomalous nature of the explicit grant of liability for ordinary negligence found in $\S 16-31-6-1$ once again rears its ugly head. Absent this statutory imposition of liability, the Good Samaritan Law would presumably abrogate an EMT's common law liability for ordinary negligence when rendering care "gratuitously" and "in good faith." As long as the statutory imposition of liability remains in place, however, the liability of EMTs for ordinary negligence would seem unaffected by an invocation of the narrowly-construed Good Samaritan Law.

This is undoubtedly a strange result. In passing Good Samaritan laws, the animating legislative purpose is to "encourage physicians, and sometimes others, including laypersons, to render emergency care at the scene of an accident without fear of common law liability if they fail to exercise reasonable care when providing the emergency care." 180 The current statutory arrangement is such, however, that it provides no immunity protection to EMTs, quite certainly some of the very people whose gratuitous emergency assistance the legislature had hoped to encourage. An off-duty EMT assisting at an emergency scene will be exposed to a greater degree of liability than his non-EMT counterparts; the safest choice for an off-duty EMT would be to not render gratuitous assistance at an accident or emergency.

177. Id.

178. IND. CODE § 16-31-6-1(a) (2003).

179. Beckerman, 614 N.E.2d at 612 .

180. Id. 


\section{The Role of Firefighter/EMTs}

The maintenance of a standard of ordinary negligence against EMTs becomes substantially more complicated after considering the extensive overlap between EMS and the fire service. Over two-thirds of Indiana's EMS organizations are fire departments. ${ }^{181}$ Many, if not most, of the EMS providers at these fire departments will also be firefighters. Under the ITCA, ${ }^{182}$ "an employee acting within the scope of the employee's employment is not liable if a loss results from [...] $[\mathrm{t}]$ he performance of a discretionary function." 183 Also under the ITCA, firefighters are generally immune from suit for losses resulting from the exercise of their official duties. ${ }^{184}$ The ITCA, however, specifically exempts the provision of medical care from the activities for which it provides immunity protections. ${ }^{185}$ The result is that a firefighter/EMT has immunity for firefighting and rescue efforts, but not for subsequent emergency medical care.

This strange arrangement is impractical and would seem to discourage a firefighter/EMT from performing or assisting in emergency medical care unless under a preexisting duty to do so. In any rescue situation, there are likely both fire and ambulance personnel on scene. If the fire crew is composed of firefighter/EMTs, a well-advised firefighter/EMT will act only up to the limits of firefighting and rescue services, and cease at the initiation of medical care. This is a problematic outcome in and of itself, in that the best patient care flows from the collaboration and assistance of all personnel on scene, but it also illustrates another potential problem with these competing schemes of liability-at what point does rescuing someone end and medical care begin?

Though there is little statutory guidance on "medical care" as used in the ITCA, the Indiana Code does define "health care" in a number of places: as defined in the section addressing patient consent, health care means "any care, treatment, service, or procedure to maintain, diagnose, or treat an individual's physical or mental condition." 186 In the definitions accompanying the Act, "health care" is defined as "an act or treatment performed or furnished, or that should have been performed or furnished, by a health care provider for, to, or on behalf of a patient during the patient's medical care, treatment, or confinement." 187 In the definition section for the "Civil Law and Procedure" title of the Indiana Code (the title containing the ITCA), one of the definitions proffered for "health care services" 188 is "any services by individuals certified as"

181. EMS SURVEY: REPORT, supra note 157 , at 7.

182. IND. CODE § 34-13-3-3 (2006).

183. IND. CODE § 34-13-3-3; § 34-13-3-3(7).

184. See generally Fowler v. Brewer, 773 N.E.2d 858 (Ind. Ct. App. 2002).

185. IND. CODE § 34-13-3-3(7) (2006) ("[T] he provision of medical or optical care as provided in IC 34-6-2-38 shall be considered as a ministerial act").

186. § 16-36-1-1 (1993).

187. $\S 34-18-2-13(1998)$.

188. The title offers no definition for "medical care." See § 34-6-2 (2007). 
EMTs. ${ }^{189}$ "[H]ealth care" or "health care services" likely encompasses more actions than "medical care," complicating the inquiry into exactly what constitutes "medical care" for purposes of governmental immunity.

For example, if a passenger in a motor vehicle accident needs to be extricated, and a firefighter is positioned behind the passenger in order to hold and stabilize the passenger's cervical spine, does that constitute medical care? If Indiana defines "medical care" too broadly under the ITCA, rescue activities that the legislature could hardly have intended to exclude from the protections of governmental immunity could plausibly fall outside of its protections.

Since the Indiana Code provides no guidance on the scope of "medical care," a foray into an English language dictionary is warranted. The first definition proffered in the Merriam-Webster Online Dictionary for "medical" is: "of, relating to, or concerned with physicians or the practice of medicine." Similarly, the American Heritage Dictionary defines "medical" as: "[o]f or relating to the study or practice of medicine." As shaped by the definitions from these (concededly, non-legal) sources, a reasonable working definition for "medical care" is care which constitutes the practice of medicine. Such a definition also conforms to a plain reading of the text.

Even armed with what appears to be a straightforward working definition for "medical care," it remains difficult to determine how a court might categorize the activities that a firefighter/EMT performs at a typical fire and/or rescue operation. There is no way to predict where a court might draw the line in determining what constitutes "medical care" in a situation with as much fluidity as a rescue scenario involving personnel who are both firefighters and EMTs. The difficulty of predicting the scope of "medical care" as it relates to the ITCA leaves open the possibility that a court could apply governmental immunity protections to emergency medical actions that fall short of constituting the practice of medicine.

\section{The Prevalence of Shiftwork}

As long as the public requires around-the-clock emergency medical services, shiftwork will remain an unavoidable necessity in EMS. Shift duration can include lengths of eight, ten, twelve, fourteen, sixteen, or twenty-four hours, with EMS providers working an average of fifty-four total hours per week. ${ }^{192}$ Long work hours, like those required in EMS, "have been clearly

189. § 34-6-2-55 (2006).

190. MERRIAM-WEBSTER ONLINE DiCTIONARY, available at http://www.merriamwebster.com/ dictionary/medical.

191. AMERICAN HERITAGE Dictionary OF THE ENGLiSh LANGUAGE (4th ed. 2000), available at $\mathrm{http}: / / \mathrm{www} \cdot$ bartleby.com/61/8/M0190800.html.

192. INT'L AsSOC. OF FIRE CHIEFS, THE EFFECTS OF SLEEP DEPRIVATION ON FIRE FIGHTERS AND EMS RESPONDERS 46-47 (2007), http://www.iafc.org/associations/4685/files/ progsSleep_SleepDeprivationReport.pdf (last visited Jul. 7, 2008) [hereinafter SLEEP DEPRIVATION REPORT]. 
linked to errors in tasks that require vigilance and focused alertness, such as driving an ambulance and providing patient care."193 Furthermore, "[t]he episodic and unpredictable nature of [EMS] work is associated with fragmented sleep and overall increase in fatigue." 194 The consequences of sleep deprivation are profound:

[g]etting fewer than six hours of sleep during one sleepwake cycle can affect coordination, judgment and reaction time $[. .].[\mathrm{T}]$ he performance of a sleep-deprived worker is similar to that of an intoxicated person. [P] eople with 24 hours of sustained wakefulness [perform] tasks [...] at a level comparable to those with $0.10 \%$ blood-alcohol content. ${ }^{195}$

In addition to sleep deprivation, EMS shiftwork also creates an "increased risk of depression, hypertension, digestive disorders, immunosuppression, diabetes, obesity and a host of other mental and physical health problems."196 While EMS organizations can take steps to mitigate the harmful effects of sleep deprivation on EMT health and work performance, the nature of EMS work will always require EMTs to push their cognitive and physical capabilities beyond normal bounds.

\section{E. Administrative Liability}

This Note takes the position that Indiana ought to provide some sort of immunity from liability to EMTs. The probable rallying cry of those who would oppose such a proposal is that, by providing immunity, the state effectively condones the negligent acts of its EMS personnel. Those alarmed by any potential vacuum in culpability need look no further than the Indiana Administrative Code ("IAC") for solace. The IAC expressly provides that "[a]n emergency medical technician shall not act negligently, recklessly, or in such a manner that endangers the health or safety of emergency patients or the members of the general public."197 Enforcement of this administrative liability falls to the Indiana Department of Homeland Security, which may, as the agency that

193. W. Ann Maggiore, Sleep Deprivation Study Details Effects of Shiftwork in EMS, J. EMERGENCY MED. SERVS. (Nov. 2007), available at http:/www.jems.com/news_and_articles/ columns/Maggiore/Sleep_and_Shiftwork.html (citing SLEEP DEPRIVATION REPORT, supra note 191).

194. Id.

195. Terry Nugent, Around the Clock: The Effect of Night Shifts on Your Health and Safety, J. EMERGENCY MED. SERVS. 92-

100 (Mar. 2007), available at http://www.jems.com/Images/March_2007_Around_the_Clock_ tcm16-90471.pdf.

196. Maggiore, supra note 193.

197. 836 IND. ADMIN. CoDE § 4-4-1(e)(2) (2004). 
issues EMS certifications, take action against an EMS provider's certification, including suspension, revocation, or requiring remedial education. ${ }^{198}$ Thus, administrative liability for negligence provides a safety net to ensure the same standard of care as civil liability does, but in a more appropriate way-levying administrative penalties against providers and organizations, ensuring a reasonable standard of care without imposing the burdens of civil liability upon overworked and underpaid public safety personnel.

\section{CONCLUSION}

Given the copious legal and policy considerations, a grant of immunity to EMTs from civil liability for acts of ordinary negligence is appropriate. The possible avenues through which to achieve this end are as numerous as the statutes which touch upon prehospital liability. The first and best option is an explicit statutory grant of immunity in place of the particularly anomalous Indiana Code $\S 16-31-6-1$. Explicit statutory immunity is the path chosen by all of the states surrounding Indiana, ${ }^{199}$ and is the one that most unambiguously confers immunity upon EMTs. Such a statute allows the General Assembly to endorse the abundant policies supporting immunity and to encourage EMS providers to enter the field without an unreasonable risk of legal liability. If the current statute remains unchanged, the continued existence of this code provision mandating liability for negligence serves as a potential stumbling block for an attempt to confer immunity via any other statute.

The General Assembly may also revisit the ITCA provision excluding "medical care" from governmental immunity protections as another option. Since the ITCA currently contains no definition for "medical care,"200 the legislature could explicitly exclude prehospital emergency medical services from such a definition. This simple definitional change would bring EMTs into the fold of governmental immunity conferred by the statute. This approach would not apply to private EMS agencies, an obvious weakness. Such a result is less satisfactory than giving an express statutory grant of immunity to all EMTs, but private EMS agencies may be better situated to absorb the financial impact of a civil judgment rendered against them.

The General Assembly may also opt to use the Indiana Medical Malpractice Act, specifically the Patient's Compensation Fund, as a tool of indemnity. Given the Patient's Compensation Fund's ostensible financial solvency, ${ }^{201}$ the General Assembly could amend the Act to provide for funds to be drawn from it to pay judgments rendered against EMTs for acts of ordinary negligence relating to prehospital care. This proposal requires no revision to $\S 16-31-6-1$ because that section's liability and this indemnity can exist simultaneously, and

198. See generally 836 IND. ADMIN. CoDE $\S 4-4-1$ et seq. (2007).

199. See Part IV.A, infra.

200. See Part VI.C, infra.

201. See Part V.B, infra. 
indemnity ensures that patients receive compensation for their injuries without imposing the financial burdens of civil judgments on already-strained EMS systems.

The lack of Indiana EMS providers questioning the General Assembly's willingness to put them out on a limb with this strange statutory liability likely corresponds to a lack of negligence actions brought against EMTs generally. Claims filed against EMTs, however, are on the rise and the existence of civil liability for ordinary negligence discourages people from pursuing work in EMS by encouraging unnecessarily expansive liability against them. The General Assembly must re-visit the issue of liability for prehospital providers or else risk undermining policy goals as related to the fostering of public safety in Indiana. 
